This item was submitted to Loughborough's Research Repository by the author.

Items in Figshare are protected by copyright, with all rights reserved, unless otherwise indicated.

\title{
Price-cap regulation in the English and Welsh water industry: a proposal for measuring productivity performance
}

\section{PLEASE CITE THE PUBLISHED VERSION}

http://dx.doi.org/10.1016/j.jup.2016.04.002

\section{PUBLISHER}

(C) Elsevier

VERSION

AM (Accepted Manuscript)

\section{PUBLISHER STATEMENT}

This work is made available according to the conditions of the Creative Commons Attribution-NonCommercialNoDerivatives 4.0 International (CC BY-NC-ND 4.0) licence. Full details of this licence are available at: https://creativecommons.org/licenses/by-nc-nd/4.0/

\section{LICENCE}

CC BY-NC-ND 4.0

\section{REPOSITORY RECORD}

Maziotis, Alexandros, David S. Saal, Emmanuel Thanassoulis, and Maria Molinos-Senante. 2019. "Price-cap Regulation in the English and Welsh Water Industry: A Proposal for Measuring Productivity Performance". figshare. https://hdl.handle.net/2134/21948. 


\title{
PRICE-CAP REGULATION IN THE ENGLISH AND WELSH WATER INDUSTRY: A PROPOSAL FOR MEASURING PRODUCTIVITY PERFORMANCE
}

\author{
Alexandros Maziotis ${ }^{a, b}$, David S. Saal ${ }^{b, c}$, Emmanuel Thanassoulis ${ }^{b}$, María Molinos-Senante ${ }^{d, e, f^{*}}$ \\ ${ }^{a}$ Foundazione Eni Enrico Mattei, Isola di San Giorgio Maggiore 8, Venice, Italy. \\ ${ }^{\mathrm{b}}$ Aston Business School, Aston University, Birmingham B4 7ET, United Kingdom. \\ ${ }^{c}$ Loughborough University, Leicestershire LE11 3TU, United Kingdom \\ ${ }^{\mathrm{d}}$ Departamento de Ingeniería Hidráulica y Ambiental, Pontificia Universidad Católica de Chile, \\ Av. Vicuña Mackenna 4860, Santiago, Chile (E-mail: mmolinos@uc.cl) \\ ${ }^{\mathrm{e}}$ Escuela de Arquitectura e Instituto de Estudios Urbanos, Pontificia Universidad Católica de \\ Chile, El Comendador 1916, Santiago, Chile \\ ${ }^{f}$ Centro de Desarrollo Urbano Sustentable CONICYT/FONDAP/15110020, Av. Vicuña Mackenna \\ 4860, Santiago, Chile. \\ *Corresponding Author: E-mail: mmolinos@uc.cl
}

\begin{abstract}
:
Privately owned water utilities typically operate under a regulated monopoly regime. Price-cap regulation has been introduced as a means to enhance efficiency and innovation. The main objective of this paper is to propose a methodology for measuring productivity change across companies and over time when the sample size is limited. An empirical application is developed for the UK water and sewerage companies (WaSCs) for the period 1991-2008. A panel index approach is applied to decompose and derive unit-specific productivity growth as a function of the productivity growth achieved by benchmark firms, and the catch-up to the benchmark firm achieved by less productive firms. The results indicated that significant gains in productivity occurred after 2000, when the regulator set tighter reviews. However, the average WaSC still must improve towards the benchmarking firm by $2.69 \%$ over a period of five years to achieve comparable performance. This study is relevant to regulators who are interested in developing comparative performance measurement when the number of water companies that can be evaluated is limited. Moreover, setting an appropriate $\mathrm{X}$ factor is essential to improve the efficiency of water companies and this study helps to achieve this challenge.
\end{abstract}

Keywords: panel index numbers, productivity decomposition, regulation, $\mathrm{X}$ factor, water industry. 


\section{INTRODUCTION}

The water and wastewater industries usually provide services under a regulated monopoly regime. Without competitive markets, operators face fewer incentives towards efficiency and innovation (Marques et al., 2011). However, at the country level, the existence of more than one company allows for competition by comparison, or yardstick competition. In general, benchmarking and total factor productivity (TFP) analysis represent key tools in business economics (O'Donnell, 2004); in the water industry benchmarking assumes a strategic importance as a way to replicate markets (Guerrini et al., 2013). Benchmarking can help companies deduce whether they follow better practices in relation to their counterparts (Gonzalez-Gomez et al., 2013).

The use of benchmarking has been expanding for regulatory services have been expanding. In the water industry, benchmarking is applied in regulation for yardstick competition (e.g. England and Wales, Colombia and some States in Australia) or for sunshine regulation (e.g. Portugal) (Marques et al., 2011). Yardstick competition is used to update tariffs by the use of price-cap regulation (CPI-X). Sunshine regulation is based on comparing and displaying publicly the performance of the regulated companies. Hence, different stakeholders are able to gain knowledge about company performance.

In CPI-X price-cap regulation, the regulated business is allowed to increase its prices over a particular period by the change in the consumer price index (CPI), minus (or plus) an X factor. This factor reflects the degree to which the regulator believes the business can improve their productivity; it is therefore known as productivity offset. Nevertheless, the $\mathrm{X}$ factor can also incorporate other factors, such as an allowance for the extra costs associated with required improvements in quality. The setting of the $\mathrm{X}$-factor value is always the subject of considerable debate (Coelli and Walding, 2006). It includes the measurement of industry-level annual productivity growth using historic data and firm-level relative efficiency using average-based and frontier-based methods (benchmark techniques). When companies are regulated under the same framework, the regulator can compare the performance of each company against the performance of the others in the industry.

Measurement of TFP changes can provide useful information in the setting of $X$ factors in CPI-X regulation. First, it provides the regulator with a means of evaluating whether productivity improvements have been achieved during the past regulatory period. Second, the assessment of TFP provides insights into what further efficiency improvements are available in the forecast period (Marques and Monteiro, 2003; Lawrence and Kain, 2012). Alternative approaches have 
been proposed to refine regulatory incentive mechanisms, such as adjustments based on sale price, revenue, operating income, and profit after tax (Ye and Tiong, 2003). In this context, Pellegrino et al. (2011) proposed a risk-based approach that combines the use of real options theory and Monte Carlo simulation. To illustrate the usefulness of their proposal, the authors developed an empirical application for the Italian water industry.

Since 1989, when the English and Welsh water industry became privatised and regulated, the price-cap regulation applied by the Water Services Authority (Ofwat) has attracted worldwide interest (Barrett and Wallace, 2011). The price-cap scheme in England and Wales has the form of $\mathrm{RPI} \pm \mathrm{K}$, where $\mathrm{RPI}$ is the retail price index and $\mathrm{K}$ determines the average value of price rises above the current rate of inflation (RPI) for the next five years.

Several researchers have assessed the productivity change of the water industry in England and Wales. Some have evaluated the impact of privatization on the efficiency and productivity of water companies (Ashton, 2000; Saal and Parker, 2000, 2001; Marques, 2008). Other have focused on evaluating the impact of regulation on productivity growth (Saal and Reid, 2004; Erbetta and Cave, 2007; Saal et al., 2007; Bottaso and Conti, 2009; Maziotis et al., 2009; Portela et al., 2011; Maziotis et al., 2012 Molinos-Senante et al., 2014; Maziotis et al., 2015)

Despite of the wide number of studies aimed toward assessing the productivity change of the regulated water industry in England and Wales, to the best of our knowledge, none of them extended their methodologies to setting the $\mathrm{X}$ factor for the English and Welsh water and sewerage regulated companies. Researchers have developed DEA (Coelli and Walding, 2006) or index-number approach (Lawrence and Diewert, 2006; Bernstein et al., 2006) to measure productivity growth and propose $\mathrm{X}$ factors in regulated industries that include the water supply industry in Australia, the electricity network in New Zealand, and the telecommunication industry in Peru. They illustrate the usefulness of computing the TFP for setting the $X$ factor in terms of providing a scientific basis to regulatory decision-making. The main advantage of nonfrontier techniques, such as the index-number approach is that it can be employed to decompose productivity growth regardless of the number of inputs and outputs specified, even in cases where the number of observations is extremely limited (Fox et al. 2003). This advantage is of outmost significance in the framework of regulated industries where the number of companies operating at the country level might be small.

In this context, this study focused on the English and Welsh water industry for two main reasons. First, since the English and Welsh water industry became privatised and regulated in 1989 , this has become a paradigmatic case and several countries have implemented the same 
approach to regulating their water industries (Barrett and Wallace, 2011). Hence, the methodological approach proposed here is broadly applicable. Second, Ofwat publishes each year at its webpage the most relevant information about the water industry in England and Wales at the company level. Hence, the availability of data allowed us to carry out the empirical analysis.

Against this background, the objectives of this paper are twofold. The first is to assess the productivity growth of the UK industry from 1991 to 2008 when the number of observations is extremely limited. The second is to test the impact of quality on our productivity measures following the approaches by Lynk (1993), Hunt and Lynk (1995), and Saal and Parker (2001). Thus, quality-adjusted unit-specific productivity growth is decomposed into two additional factors, quality catch-up by less productive (laggard) firms and quality growth by the benchmark firm. Finally, the analysis provides insight into how companies' productivity changed during the regulatory price review period.

From a policy perspective, the methodology and the empirical application carried out in this study are of great interest for utility managers and regulators. Since the water provider usually is a local or regional monopoly, each firm has a strong incentive to maximize productivity performance to achieve lower unit costs. From the regulator's point of view, benchmarking is intended to impose performance pressure similar to competition. Moreover, the methodology proposed for measuring productivity change for WaSCs provides essential information to propose an $\mathrm{X}$ factor for each company to be applied in CPI-X price regulation.

\section{METHODOLOGY}

The methods used to compute TFP can be categorised as frontier and non-frontier, each one with advantages and disadvantages depending on context. Taking into account the objectives of this study, the importance of the derivation of productivity measures across firms and over time using index numbers (non-frontier approach) is twofold. First, frontier methods such as DEA or SFA require a relatively large number of observations to specify an efficient frontier, whereas an index-number approach allows meaningful comparative performance measurement even if the number of available observations is limited (Fox et al., 2003; Diewert and Lawrence, 2006; Hwand and Lee, 2013). Second and more importantly, the index-number approach is particularly applicable to comparative performance measurement under regulation, where consideration of both water companies (in productivity terminology it is known as spatial dimension) and temporal differences in TFP is necessary for setting appropriate regulated prices (Fox et al., 2003). 


\subsection{Quality-unadjusted assessment of total factor productivity}

To assess the productivity growth of the WaSCs, we follow an index-number approach (Maziotis et al., 2009; 2012). It allows the decomposition of a unit-specific index into the productivity growth achieved by benchmark companies and the contribution of productivity catch-up by less productive firms. In the first step, measures of temporal (unit-specific) productivity across time for each firm are provided (Saal and Parker, 2001). Next, productivity comparisons across companies at any given year (multilateral spatial comparisons) are calculated by using a multilateral Fisher index (Ball et al. 2001; Fox et al., 2003; Pierani, 2009). Then, by reconciling together the spatial and temporal productivity measures into relative productivity measures, a single index is provided that consistently measures productivity performance changes both across firms and over time (Hill, 2002; 2004). Finally, the reconciliation of the spatial, temporal, and relative productivity measures allows us to decompose the unit-specific index number based productivity growth as a function of the productivity growth achieved by benchmark firms, and the catch-up to the benchmark firm achieved by less productive firms ${ }^{1}$.

Following Waters and Thretheway (1999), Salerian (2003), and Saal and Parker (2001), a temporal Fisher index-number approach is used to calculate unit-specific productivity growth. It measures differences in the temporal dimension for the given firm. Eq. (1) describes the Temporal Fisher output $\left(Y_{i, t}\right)$ and input indexes $\left(X_{i, t}\right)$ between two time periods $l$ and $t$, where $l$ is the base period in the case of $m$ outputs and $n$ inputs for a firm $i$ :

$Y_{i, t}=\left[\frac{\sum_{m=1}^{M} P_{l}^{m} Y_{t}^{m}}{\sum_{m=1}^{M} P_{l}^{m} Y_{l}^{m}} x \frac{\sum_{m=1}^{M} P_{t}^{m} Y_{t}^{m}}{\sum_{m=1}^{M} P_{t}^{m} Y_{l}^{m}}\right]^{1 / 2} \quad X_{i, t}=\left[\frac{\sum_{n=1}^{N} W_{l}^{n} X_{t}^{n}}{\sum_{n=1}^{N} W_{l}^{n} X_{l}^{n}} x \frac{\sum_{n=1}^{N} W_{t}^{n} X_{t}^{n}}{\sum_{n=1}^{N} W_{t}^{n} X_{l}^{n}}\right]^{1 / 2}$

where $Y_{t}^{m}$ and $Y_{l}^{m}$ denote the quantities for the $m t h$ output for periods $t$ and $l$ respectively, whereas $X_{t}^{n}$ and $X_{l}^{n}$ present the quantities for the $n t h$ input for periods $t$ and $l$ respectively. Moreover, $P_{t}^{m}$ and $P_{l}^{m}$ are the prices for $m t h$ output, while $W_{t}^{n}$ and $W_{l}^{n}$ denote input prices. A temporal Fisher productivity index, $T F P_{i, t}$ is then constructed as a ratio of Fisher output index relative to Fisher input index, which takes the value 1 in the year $l$ (base period):

$T F P_{i, t}=\frac{Y_{i, t}}{X_{i, t}}$

To measure productivity performance across companies at any given year (multilateral spatial comparisons), a spatial Fisher index is derived using the multilateral-EKS method. Bilateral

\footnotetext{
${ }^{1}$ Further details can be found at the appendix.
} 
Fisher output and input indexes between two firms $i$ and $j$ in the case of $m$ outputs and $n$ inputs are respectively, $Y_{i, j}^{S}$ and $X_{i, j}^{S}$ :

$Y_{i, j}=\left[\frac{\sum_{m=1}^{M} P_{j}^{m} Y_{i}^{m}}{\sum_{m=1}^{M} P_{j}^{m} Y_{j}^{m}} x \frac{\sum_{m=1}^{M} P_{i}^{m} Y_{i}^{m}}{\sum_{m=1}^{M} P_{i}^{m} Y_{j}^{m}}\right]^{1 / 2} \quad X_{i, j}=\left[\frac{\sum_{n=1}^{N} W_{j}^{n} X_{i}^{n}}{\sum_{n=1}^{N} W_{j}^{n} X_{j}^{n}} x \frac{\sum_{n=1}^{N} W_{i}^{n} X_{i}^{n}}{\sum_{n=1}^{N} W_{i}^{n} X_{j}^{n}}\right]^{1 / 2}$

where $Y_{i}^{m}$ and $Y_{j}^{m}$ denote the quantities for the $m t h$ output for firms $i$ and $j$ respectively, whereas $X_{i}^{n}$ and $X_{j}^{n}$ present the quantities for the $n t h$ input for firms $i$ and $j$ respectively. Moreover, $P_{i}^{m}$ and $P_{j}^{m}$ are the prices for $m t h$ output, while $W_{i}^{n}$ and $W_{j}^{n}$ denote input prices. The resulting Fisher output and input indices, $Y_{i j}^{S}$ and $X_{i j}^{S}$ are as follows:

$Y_{i j}^{S}=\prod_{k=1}^{I}\left[Y_{i k} \times Y_{k j}\right]^{\frac{1}{I}} \quad X_{i j}^{S}=\prod_{k=1}^{I}\left[X_{i k} \times X_{k j}\right]^{\frac{1}{I}}$

The spatial Fisher productivity index is then constructed as a ratio of the Fisher output index relative to Fisher input index:

$T F P_{i, j}^{S}=\frac{Y_{i, j}^{S}}{X_{i, j}^{S}}$

In Eq. 5 if one firm is arbitrarily chosen as a base firm and set $j=b$, then each spatial measure, is a measure of firm $i$ relative to the chosen base firm. Hence, productivity relative to the base firm's productivity can be expressed as $T F P_{i}^{S}=\frac{Y_{i}^{S}}{X_{i}^{S}}$.

In order to simultaneously measure and decompose the productivity growth of any firm in the sample across time and relative to other firms, it is necessary to reconcile the spatial productivity measures with the underlying unit-specific chained productivity of each firm.

According to Hill $(2002 ; 2004)$, firm $i$ 's relative productivity change over time $\left(T F P_{i, t}^{R}\right)$ is determined as the geometric average of the $I$ alternative potential estimates of relative productivity. It is derived by employing the chained time trends (Is it TFP (CH) you need to define here and spatial productivities (TFP(S) of all the I firms in the sample:

$T F P_{i, t}^{R}=\left[\prod_{j=1}^{I}\left[\left(T F P_{j, t}^{C H} \times T F P_{j, 1}^{S}\right) \times \frac{T F P_{i, t}^{S}}{\operatorname{TFP}_{j, t}^{S}}\right]\right]^{\frac{1}{I}}$

Thus, when $i=j, T F P_{i, t}^{R}$ can be simply expressed as the product of the firm's own chained productivity index and its spatial productivity measure in year $l: T F P_{i, t}^{R}=T F P_{i, t}^{C H} \times T F P_{i, 1}^{S}$. In contrast, for the alternative $I-1$ estimates when $i \neq j, T F P_{i, t}^{R}$ can also be expressed as a 
function of any other firm $j$ 's relative productivity index calculated as $T F P_{j, t}^{R}=T F P_{j, t}^{C H} x T F P_{j, 1}^{S}$, and the spatial productivity of firm $i$ relative to firm $j$, which given the definition of our spatial productivity measures, can be expressed as $\frac{T F P_{i, t}^{S}}{T F P_{j, t}^{S}}$.

If $\operatorname{TFP}_{i, t}^{R}>1$, then firm $i$ improved its productivity relative to the base firm from time $/$ to $t$, whereas a value lower than 1 indicates that relative productivity of firm $i$ has declined relative to that of the base firm in period $\mathrm{L}$.

\subsection{Quality-adjusted assessment of total factor productivity}

A second assessment of productivity change considering the quality of service is also performed (discussed further in section 3). WaSCs have carried out substantial capital investment programs related to water and sewerage treatment since privatisation (Portela et al. 2011). As these were made in response to increasingly stringent environmental regulation, including European Union directives (Maziotis et al., 2009), it is assumed that quality improvements are exogenously determined (Saal \& Parker, 2000). Consequently, the first step to estimate quality-adjusted indices involves the construction of quality-adjusted water and sewerage outputs. Following Lynk (1993), Hunt and Lynk (1995), and Saal and Parker (2001), a drinking water quality index (DWQI) and a sewerage treatment quality index (STQI) are defined. Once both indices are estimated, quality-adjusted indices are produced by repeating the procedures described previously (section 2.1). Thus, spatially consistent quality-adjusted output indices $\left(Y_{i, t}^{S, Q}\right)$ are first produced. A spatial implicit quality index $\left(Q_{i, t}^{S}\right)$ can also be derived to measure the implied difference in quality relative to the base firm as:

$Q_{i, t}^{S}={ }^{S, t}{ }^{S, Q} / Y_{i, t}^{S}$

In an analogous manner, measures can be derived for relative quality-adjusted output indices over time $Y_{i, t}^{R, Q}$ and an implicit quality index $Q_{i, t}^{R}$ that measures the implied difference in quality over time relative to the base firm at the base period as:

$Q_{i, t}^{R}=Y_{i, t}^{R, Q} / Y_{i, t}^{R}$ 
Moreover, measures of unit-specific quality-adjusted output indices over time, $Y_{i, t}^{U S, Q}$ and an implicit quality index over time $Q_{i, t}^{U S}$ that measures the implied difference in unit-specific quality over time are calculated as:

$Q_{i, t}^{U S}=Y_{i, t}^{U S, Q} / Y_{i, t}^{U S}$

By adjusting TFP measures for quality, an alternative decomposition of unit-specific production growth can be derived. Hence, the productivity index can be decomposed into the catch-up in quality regarding productivity achieved by less productive firms and the quality growth in productivity of the base firm in a multilateral context. Given $Q_{i, t}^{S}$ measures of the catch-up in quality, $Q_{i, t}^{C}$ can be constructed as $Q_{i, t}^{C}=Q_{i, t}^{S} / Q_{i, 1}^{S}$.

If $Q_{i, t}^{C}>1$, then the firm $i$ improved its quality in terms of productivity relative to the base firm from year 1 to year $t$, whereas a value lower than 1 indicates that relative quality regarding productivity of firm $i$ has declined relative to that of the base firm.

\subsection{Estimation of $X$ factors under price-cap regulation}

The above spatial, unit-specific, and relative productivity change measures over time provide information regarding the productivity gains achieved by less productive firms and the productivity growth achieved by the benchmark firm (backward-looking). However, the potential (anticipated) productivity catch-up of laggard firms and the estimate of how the top performing company improved its productivity over time (frontier shift) can be applied in setting the $X$ factors in regulated industries under price-cap regulation (forward-looking).

Based on spatial comparisons in a given year, an estimate of the potential (anticipated) annual productivity improvements $\left(T F P_{i}^{P I}\right)$ of a firm $i$ can be provided if it was required to catch up to the best firm over a period of $T$ years:

$T F P_{i}^{P I}=\left(\frac{1}{T F P_{i}^{S}}\right)^{1 / T}$

Finally, the consistent rate of productivity growth of the best firm in the sample based on the relative productivity change measures, $T F P_{b, t}^{U S}$, provides an estimate of how the top performing company improved its productivity over time (frontier shift). 
Section 4.3 shows an example how an $\mathrm{X}$ factor can be computed based on the productivity growth of the best water company. For reference, Coelli and Walding (2006) employed DEA methods to provide a framework for including productivity gains in the $\mathrm{X}$ factor for the Australian water supply industry.

\section{SAMPLE AND DATA DESCRIPTION}

The empirical application covers a balanced panel of the ten English and Welsh WaSCs for the period 1991-2008. The data come from the "June Returns for the Water and Sewerage Industries in England and Wales" published by Ofwat each year at its webpage. A potential limitation of our study may be the quality of the underlying data provided by the water companies in the June returns. Urban water-connected properties and sewerage-connected properties are the proxies for water and sewerage output. Water and sewage output prices were calculated as the ratio of the appropriate turnover, as available in Ofwat's regulatory returns, to measured output. Three inputs - capital stock, labor, and "other" costs - were considered, as described below.

Following Saal and Parker (2001) and Maziotis et al. (2009, 2012), the capital stock is proxied by Modern Equivalent Asset (MEA) current cost estimates of the replacement cost of the firm's existing capital stock. MEA values for previous years based on net investment are also systematically calculated, as is necessary given the periodic substantial revisions of the companies' MEA values. We subsequently employed a user cost-of-capital approach, to calculate total capital costs as the sum of the opportunity cost of invested capital and capital depreciation relative to the MEA asset values, and construct the price of physical capital as the user cost of capital divided by the above MEA based measure of physical capital stocks (Maziotis et al., 2009). The average number of full-time equivalent (FTE) employees is available from the companies' statutory accounts. Firm-specific labour prices were calculated as the ratio of total labour costs to the average number of full-time equivalent employees. Other costs in nominal terms were defined as the difference between operating costs and total labour costs. Given the absence of data allowing a more refined break out of other costs, the UK price index for materials and fuel purchased for the purification and distribution of water, as the price index for other costs is employed; we simply deflate nominal other costs by this measure to obtain a proxy for real usage of other inputs. Table 1 presents aggregate revenues, costs, inputs and outputs for the WaSCs for selected periods of study.

To test the impact of quality on our productivity measures, quality-adjusted measures of output for water and sewerage services are calculated. These are the product of water output 
and a drinking water quality index, and sewerage output and a sewage treatment quality index, respectively.

Following Saal and Parker (2001), the DWQI is calculated as the ratio of the average percentage of each WaSC's water supply zones that are fully compliant with key water quality parameters, relative to the average compliance percentage for England and Wales in 1991. The DWQI is based on six water-quality parameters and the data were drawn from the DWI's annual reports for drinking water quality for the calendar years ending 1991-2007. We note that there are different approaches to assess water quality issues. For example, MolinosSenante et al. (2015) introduced the concept of poor customer service as an undesirable outputs. A similar approach was followed by Hernández-Sancho et al. (2012), where water losses were included in the analysis. In this study, however, quality refers to the actual quality of the drinking water supplied and wastewater treated. The STQI is defined as a weighted index of the percentage of connected population for which sewage receives primary treatment and the percentage of population for which sewage receives (at least) secondary treatment. It also implicitly includes the percentage of connected population for which sewage is not treated with a zero weight (Maziotis et al., 2009). The sewage treatment data were taken from Waterfacts for the first years 1990-91 to 1995-96 and the companies' regulatory reports for the fiscal years 1996-97 to 2007-08. 


\begin{tabular}{|c|c|c|c|c|c|c|c|c|}
\hline & Units & 1994 & 1995 & 2000 & 2001 & 2005 & 2006 & 2008 \\
\hline Revenues & $10^{6} £(2008)$ & 478.79 & 507.35 & 627.88 & 581.54 & 672.89 & 753.72 & 849.46 \\
\hline Economic Costs & $10^{6} £(2008)$ & 421.07 & 456.94 & 524.69 & 596.65 & 693.28 & 718.20 & 874.80 \\
\hline Water Connected Properties & 000s & 1666.5 & 1689.7 & 1830.4 & 1930.2 & 1982.1 & 1997.2 & 2006.1 \\
\hline $\begin{array}{l}\text { Quality-Adjusted Water } \\
\text { Connected Properties }\end{array}$ & 000s & 1510.1 & 1560.4 & 1723.7 & 1841.2 & 1908.3 & 1929.7 & 1944.2 \\
\hline $\begin{array}{l}\text { Sewerage Connected } \\
\text { Properties }\end{array}$ & 000s & 2129.8 & 2231.8 & 2212.3 & 2227.4 & 2301.7 & 2345.6 & 2379.5 \\
\hline $\begin{array}{l}\text { Quality-Adjusted Sewerage } \\
\text { Connected Properties }^{2}\end{array}$ & 000s & 1696.3 & 1726.9 & 1923.9 & 2093.9 & 2264.7 & 2318.6 & 2307.2 \\
\hline Capital & $10^{6} £(2008)$ & 19018 & 19229 & 20448 & 20817 & 21325 & 21436 & 21759 \\
\hline Number of employees & FTE & 3813 & 3774 & 2969 & 2785 & 2720 & 2751 & 2952 \\
\hline Other Inputs & $10^{6} £(2008)$ & 99.95 & 99.77 & 97.01 & 95.86 & 82.46 & 82.09 & 78.14 \\
\hline $\begin{array}{l}\text { Price for a Water Connected } \\
\text { Property }\end{array}$ & fs (2008) & 0.133 & 0.139 & 0.148 & 0.137 & 0.153 & 0.172 & 0.197 \\
\hline $\begin{array}{l}\text { Price for a Sewerage } \\
\text { Connected Property }\end{array}$ & fs (2008) & 0.136 & 0.145 & 0.182 & 0.158 & 0.180 & 0.197 & 0.219 \\
\hline $\begin{array}{l}\text { Price for a Quality-Adjusted } \\
\text { Water Connected Property }\end{array}$ & fs (2008) & 0.147 & 0.150 & 0.158 & 0.144 & 0.160 & 0.178 & 0.204 \\
\hline $\begin{array}{l}\text { Price for a Quality-Adjusted } \\
\text { Sewerage Connected Property }\end{array}$ & fs (2008) & 0.156 & 0.163 & 0.182 & 0.142 & 0.151 & 0.164 & 0.186 \\
\hline Price for Capital & fs (2008) & 0.012 & 0.014 & 0.015 & 0.018 & 0.022 & 0.022 & 0.028 \\
\hline Price for Labour & f000s (2008) & 0.022 & 0.016 & 0.027 & 0.027 & 0.034 & 0.035 & 0.037 \\
\hline Price of Other Inputs ${ }^{3}$ & fs (2008) & 0.498 & 0.514 & 0.609 & 0.619 & 0.799 & 0.881 & 1.000 \\
\hline
\end{tabular}

1. Calculated as the product of water connected properties and the average percentage of each WaSC's water supply zones fully compliant with key drinking water quality parameters.

2. Calculated as the product of sewerage connected properties and the percentage of population receiving at least secondary or higher sewerage treatment.

3. UK price index for materials and fuel purchased in purification and distribution of water

Table 1. Average revenues, costs, outputs and inputs 


\section{RESULTS AND DISCUSSION}

\subsection{Quality-unadjusted total factor productivity}

The decomposition of average unit-specific productivity growth into quality-unadjusted productivity change of the benchmark firm and quality-unadjusted average productivity catchup relative to the benchmark firm is depicted in Figure $1^{2}$.

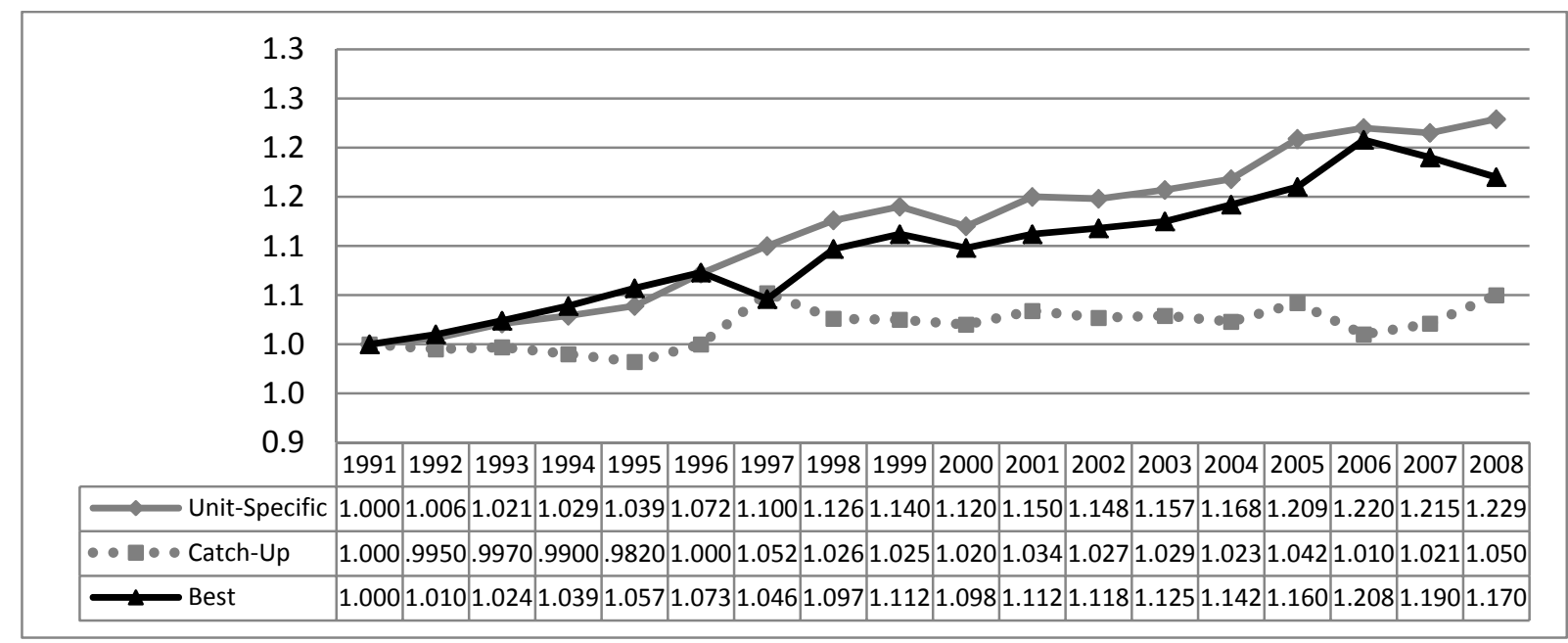

Figure 1. Decomposition of average unit-specific quality-unadjusted TFP change into benchmark TFP change and average catch-up to the benchmark firm.

Until 1995, there was negative productivity catch-up as the productivity improvements for the average company amounted to $3.9 \%$, while the benchmark company improved its productivity by $5.7 \%$. This finding suggests that the lax price caps set at privatization did not encourage average or benchmark firms to achieve high productivity levels. However, this trend was interrupted in 1995, after which both average and benchmark productivity performance significantly improved. During the years 1996-2000, when price caps were first tightened, average companies had stronger incentives to catch up to the benchmark, while the benchmark company was incentivized to continue to improve productivity. By 2000 , average cumulative productivity increased by $12 \%$ and this growth exceeded that of the benchmark firm, which achieved cumulative improvement of $9.8 \%$, thereby indicating total catch-up in productivity of $2 \%$ between 1991 and 2000 .

Significant productivity gains for the average firm relative to the benchmark firm also continued after 2000. Our results thus suggest that the implementation of even tighter price caps in 1999 further encouraged less productive firms to improve their performance relative to

\footnotetext{
${ }^{2}$ Firms have not been identified for confidentially reasons.
} 
the benchmark, even though the benchmark firm continued to improve its performance. By 2004, the cumulative measures indicate that since 1991, the average company improved its productivity by $16.8 \%$, catching up to the benchmark by $2.3 \%$, while the benchmark firm improved its productivity by $14.2 \%$. During the last price review period, average productivity growth again substantially exceeded the productivity growth of the benchmark firm, meaning high levels of productivity catch-up between 2005 and 2008, although this is largely explained by substantial declines in benchmark productivity after 2006. Overall, during the entire 19912008 period, average productivity improved by $22.9 \%$, while benchmark productivity improved by $17 \%$, allowing an average productivity catch-up of $5 \%$. Thus, all of the catch-up can be attributed to the post 1995 period, after Ofwat first tightened price caps; most of the gains can be attributed to the post-2000 period, following the even more stringent 1999 price review.

\subsection{Quality-adjusted total factor productivity}

The inclusion of quality in our productivity measures, allows us to decompose unit-specific productivity as a function of quality-adjusted catch-up in TFP achieved by less productive firms relative to the benchmark firm and the quality-adjusted TFP growth obtained by the benchmark firm. This decomposition is visualised at Figures 2, 3, and 4.

Figure 2 shows the decomposition of quality-adjusted average TFP change into qualityunadjusted average TFP change and quality change. High capital-investment programs to improve quality conditions since privatization appear to have had a positive impact on qualityadjusted output growth; consequently, quality-adjusted TFP increased more than qualityunadjusted TFP. Over the whole period, average quality-adjusted TFP improved by $51.7 \%$, whereas average quality-unadjusted TFP improved by only $22.9 \%$, implying that average estimated quality change amounted to $23.4 \%$. Much of the measured quality improvement occurred during the years 1991-2002 and with the highest level of improvement seen in the years 1999 and 2002. Thus, by 2002, average quality improved by 22\%, resulting in an increase in average quality-adjusted TFP of $40.1 \%$ and exceeded average quality-unadjusted TFP, which improved by only $14.8 \%$. After 2003 , on average, there were small improvements in quality and thus, small changes in the quality-adjusted TFP growth rate; in the last two years studied, average quality followed a slightly declining trend. Nevertheless, productivity continued to improve in the later period, suggesting that firms were able to achieve productivity improvements by reducing input usage. 


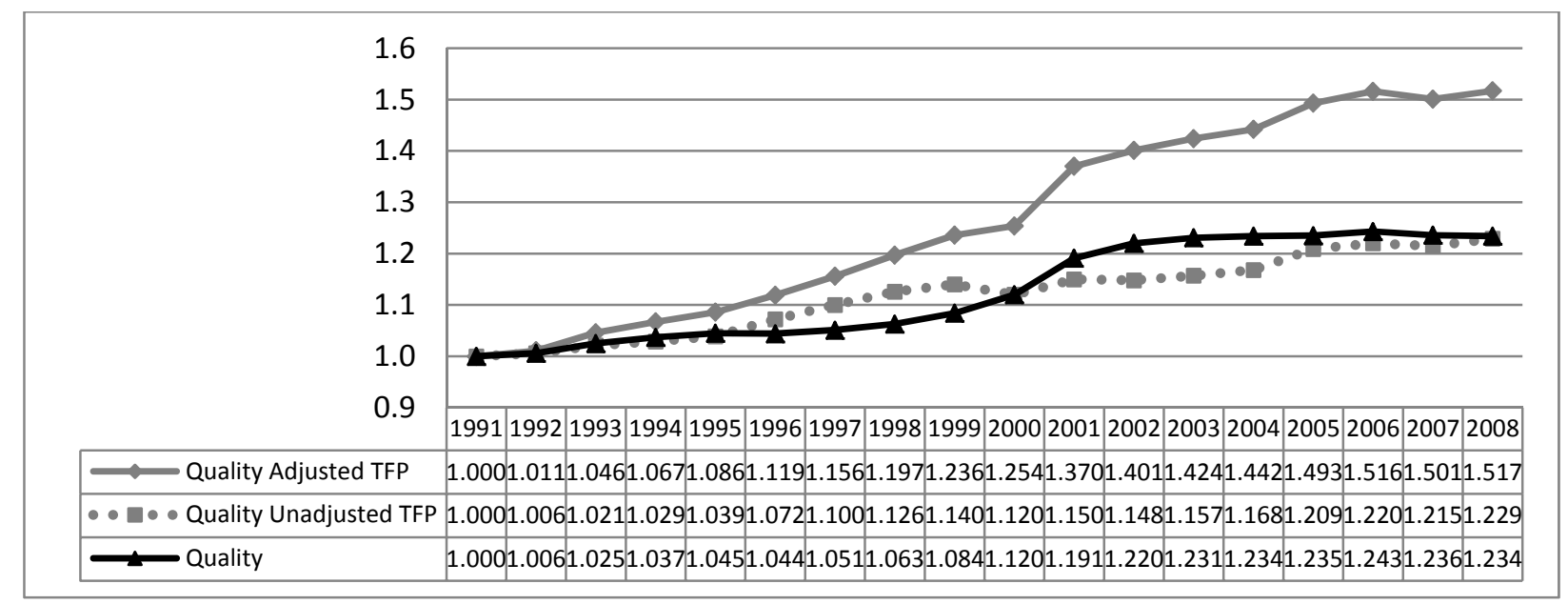

Figure 2. Decomposition of average unit-specific quality-adjusted TFP change into average unit-specific TFP and quality change.

The decomposition of quality-adjusted average unit-specific productivity growth into the quality-adjusted productivity growth of the benchmark firm and average quality-adjusted productivity catch-up is depicted in Figure 3. We find that until 1994, there were small or no catch-up gains in quality-adjusted productivity by the average company since its productivity improved by $6.7 \%$, while the benchmark company improved its productivity by $7.1 \%$. In contrast, due to sharp increases in quality between 1996 and 2002, average quality-adjusted TFP increased more rapidly than benchmark quality-adjusted TFP, thereby allowing the average company to catch up considerably, amounting to $19.5 \%$ of cumulative productivity growth for the average firm by 2002 . The average company continued to achieve a substantial level of catch-up in quality-adjusted productivity until 2005, which must be attributed to input usage reductions. Thus, relative to 1991 levels, by 2005, average quality-adjusted productivity had increased by $49.3 \%$ and exceeded that of benchmark firm, which had improved by $21.2 \%$, therefore indicating productivity catch-up of $23.2 \%$. Nevertheless, after 2005 , when a the relatively loose price review of 2004 came into effect, high levels of productivity catch-up were no longer indicative of general productivity improvements, as average quality-adjusted productivity levels were largely static after 2005. These trends instead reflect a substantial decline in the benchmark firm's productivity after 2006. Thus, the results show that after the 2004 price review, substantial productivity improvements were no longer achieved. 


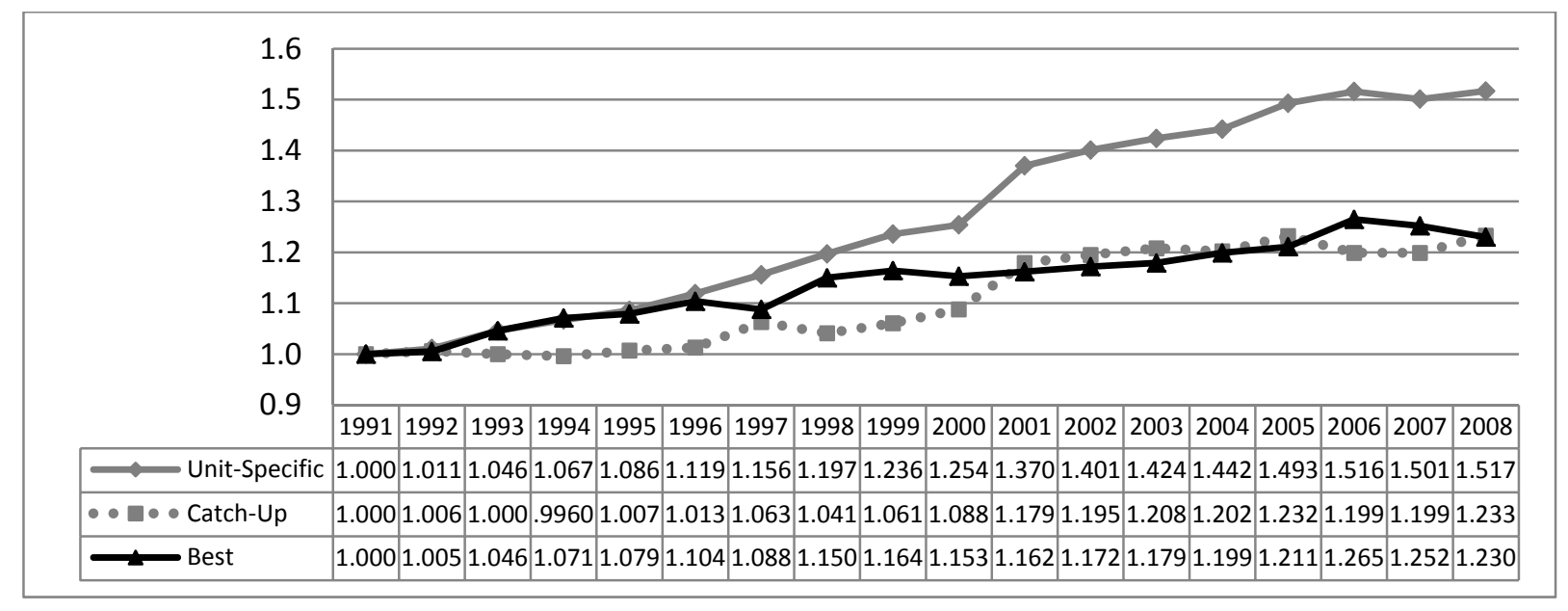

Figure 3. Decomposition of average unit-specific quality-adjusted TFP change into benchmark TFP change and average catch-up to the benchmark firm.

Figure 4 shows the decomposition of average unit-specific quality change into average quality catch-up relative to the benchmark firm and the quality change of the benchmark firm. Until 1997, there were small or no gains in average quality relative to benchmark quality, but after 1998 and for most of the period of study, average quality growth significantly exceeded benchmark quality growth, with particularly high levels of quality catch-up between 1998 and 2002. By 2005 , average quality improved by $23.5 \%$ while benchmark quality increased by $4.1 \%$ allowing average quality to catch up to the benchmark by $18.6 \%$. After 2005 , average quality continued to increase at a lower rate; however, it showed a significant decline in 2007 and in 2008, which affected the quality-adjusted TFP growth rates as evident in Figure 2; benchmark quality, however, followed a stable and moderate upward trend. We emphasize that the small quality growth of the benchmark firm does not imply that the benchmark did not achieve significant quality levels. To the contrary, the results suggest that at privatization the quality standards of the benchmark firm had already been at a high level and by 2005 , the less productive firms on average had significantly improved their quality relative to the benchmark and had finally reached the higher levels of quality of the benchmark firm. 


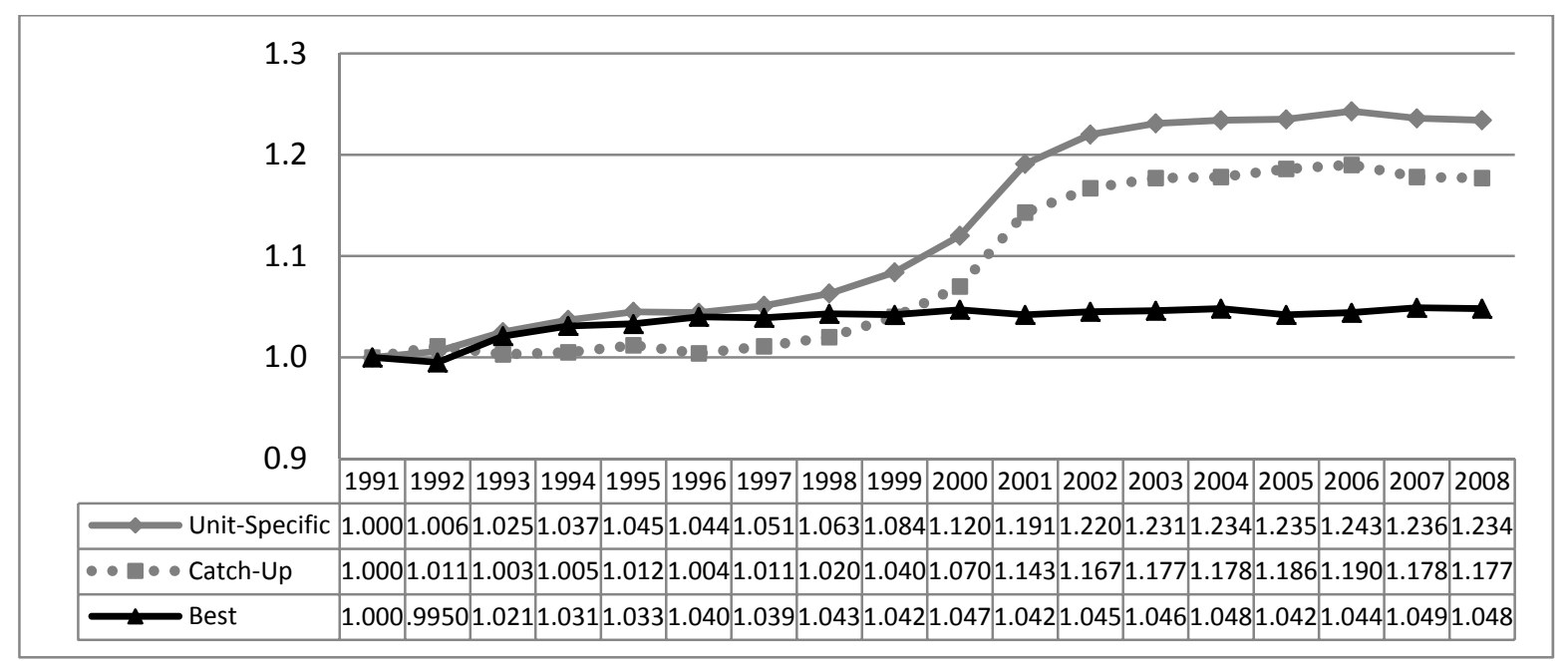

Figure 4. Decomposition of average unit-specific quality change into average quality change catch-up and benchmark quality change.

\subsection{X factors in price-cap regulation}

Calculation of the level of catch-up achieved by each company to the most productive firm and the productivity growth of the best firm based on the spatial and unit-specific productive measures over time (frontier shift) allow us to propose $X$ factors for the water and sewerage companies over a five-year period. This is illustrated by using results from the year 2008 as an example.

We assume that it is desirable to set an $X$ factor for the company $\mathrm{C} 1$ considering its productivity relative to the most productive company in 2008 , which is assumed to be the most productive firm in the sample. The potential (anticipated) productivity improvement of $\mathrm{C} 1$ to catch up to company $\mathrm{C} 5$ over time is $1.000 / 0.889=1.125$. Assuming that $\mathrm{C} 1$ should achieve $50 \%$ catch-up for total costs over a five-year period, then it should catch-up by $[1.000+(1.125-1=/ 2]=1.062$ over a five-year period. That means that $\mathrm{C} 1$ should catch up to the best firm by $(1.062)^{1 / 5}=1.012$ per year. Assuming a $(1.170)^{1 / 17}=1.009$ continuing improvement factor based on the relative productivity change of $\mathrm{C} 5$ over time, then the required productivity growth or the $\mathrm{X}$ factor for $\mathrm{C} 1$ should be calculated as: $X=$ $1.012 \times 1.009=1.021$ or $2.16 \%$ per year. Analogously, the $X$ factors are computed for the other WaSCs and for the average company. Table 2 shows the quality-unadjusted spatial productivity results and the proposed $2008 \mathrm{X}$ factors for the WaSCs. 


\begin{tabular}{|c|c|c|c|c|c|c|c|}
\hline Company & $\begin{array}{l}\text { Spatial TFP } \\
\text { quality- } \\
\text { unadjusted }\end{array}$ & $\begin{array}{c}\text { Potential } \\
\text { productivity } \\
\text { growth } \\
\text { through } \\
\text { catch-up }\end{array}$ & $\begin{array}{c}50 \% \\
\text { catch-up } \\
\text { for total } \\
\text { costs }\end{array}$ & $\begin{array}{l}\text { Catch-up } \\
\text { (\%) per } \\
\text { year }\end{array}$ & $\begin{array}{l}\text { Continuing } \\
\text { Improvement } \\
\text { Factor }\end{array}$ & $\begin{array}{l}\text { Required } \\
\text { Productivity } \\
\text { Growth }\end{array}$ & $\begin{array}{l}\mathrm{X} \text { factor } \\
\text { (\%) }\end{array}$ \\
\hline C1 & 0.889 & 1.125 & 1.062 & 1.012 & 1.009 & 1.022 & $2.16 \%$ \\
\hline C2 & 0.910 & 1.099 & 1.049 & 1.01 & 1.009 & 1.019 & $1.91 \%$ \\
\hline C3 & 0.707 & 1.414 & 1.207 & 1.038 & 1.009 & 1.048 & $4.80 \%$ \\
\hline C4 & 0.840 & 1.191 & 1.095 & 1.018 & 1.009 & 1.028 & $2.78 \%$ \\
\hline C5 & 1.000 & 1.000 & 1.000 & 1.000 & 1.009 & 1.009 & $0.93 \%$ \\
\hline C6 & 0.728 & 1.374 & 1.187 & 1.035 & 1.009 & 1.045 & $4.45 \%$ \\
\hline C7 & 0.893 & 1.120 & 1.060 & 1.012 & 1.009 & 1.021 & $2.12 \%$ \\
\hline C8 & 0.741 & 1.350 & 1.175 & 1.033 & 1.009 & 1.042 & $4.23 \%$ \\
\hline C9 & 0.769 & 1.300 & 1.150 & 1.028 & 1.009 & 1.038 & $3.79 \%$ \\
\hline C10 & 0.890 & 1.123 & 1.062 & 1.012 & 1.009 & 1.021 & $2.15 \%$ \\
\hline Average & 0.832 & 1.202 & 1.103 & 1.020 & 1.009 & 1.029 & $2.64 \%$ \\
\hline
\end{tabular}

Table 2 . Setting $X$ factors quality unadjusted for 2008

Following the same approach, $\mathrm{X}$ factors for WaSCs based on the quality-adjusted spatial productivity measures and the unit-specific productivity growth of the best company are also proposed, with the results shown in Table 3. The $X$ factors for quality-unadjusted range from $0.93 \%$ to $4.80 \%$; when quality issues are considered, the minimum $X$ factor proposed is $1.21 \%$ and the maximum one is $5.52 \%$. Hence, the variation among WaSCs in the $\mathrm{X}$ factor is slightly larger if quality is introduced in the calculations. In both cases (unadjusted and adjusted quality) the lowest proposed $X$ factor is for $\mathrm{C} 5$. These findings illustrate the importance of considering quality issues when assessing the productivity change of water and sewerage companies.

\begin{tabular}{|c|c|c|c|c|c|c|c|}
\hline Company & $\begin{array}{c}\text { Spatial } \\
\text { TFP } \\
\text { quality- } \\
\text { adjusted }\end{array}$ & $\begin{array}{c}\text { Potential } \\
\text { productivity } \\
\text { growth } \\
\text { through } \\
\text { catch-up }\end{array}$ & $\begin{array}{c}\mathbf{5 0 \%} \\
\text { catch-up } \\
\text { for total } \\
\text { costs }\end{array}$ & $\begin{array}{c}\text { Catch-up } \\
\text { (\%) per } \\
\text { year }\end{array}$ & $\begin{array}{c}\text { Continuing } \\
\text { Improvement } \\
\text { Factor }\end{array}$ & $\begin{array}{c}\text { Required } \\
\text { Productivity } \\
\text { Growth }\end{array}$ & $\begin{array}{c}\text { X factor } \\
\text { (\%) }\end{array}$ \\
\hline C1 & 0.890 & 1.124 & 1.062 & 1.012 & 1.012 & 1.024 & $2.43 \%$ \\
\hline C2 & 0.881 & 1.134 & 1.067 & 1.013 & 1.012 & 1.025 & $2.53 \%$ \\
\hline C3 & 0.693 & 1.442 & 1.221 & 1.041 & 1.012 & 1.053 & $5.33 \%$ \\
\hline C4 & 0.777 & 1.287 & 1.144 & 1.027 & 1.012 & 1.040 & $3.96 \%$ \\
\hline C5 & 1.000 & 1.000 & 1.000 & 1.000 & 1.012 & 1.012 & $1.21 \%$ \\
\hline C6 & 0.683 & 1.464 & 1.232 & 1.043 & 1.012 & 1.055 & $5.52 \%$ \\
\hline C7 & 0.878 & 1.139 & 1.069 & 1.014 & 1.012 & 1.026 & $2.58 \%$ \\
\hline C8 & 0.731 & 1.368 & 1.184 & 1.034 & 1.012 & 1.047 & $4.69 \%$ \\
\hline C9 & 0.745 & 1.342 & 1.171 & 1.032 & 1.012 & 1.045 & $4.46 \%$ \\
\hline C10 & 0.854 & 1.171 & 1.085 & 1.017 & 1.012 & 1.029 & $2.88 \%$ \\
\hline Average & 0.807 & 1.238 & 1.121 & 1.023 & 1.012 & 1.036 & $3.26 \%$ \\
\hline
\end{tabular}

Table 3. Setting X factors quality adjusted for 2008 


\section{CONCLUSIONS}

Privately owned water utilities typically operate under a regulated monopoly regime. As for other regulated utilities, benchmarking is of outmost importance to enhance efficiency. In price-cap (CPI-X) regulation, the $\mathrm{X}$ factor reflects the potential improvement of productivity for each company benchmarked. The setting of the $X$ factor value is always controversial, since different approaches can yield different results. Importantly, the $X$ factor can also incorporate service-quality factors.

For the water industry, the regulatory process in English and Welsh is an exemplary case and has been widely studied. However, despite the notable importance of setting appropriate $X$ factors, previous studies have not fully addressed this issue. To overcome this gap, and inform the regulatory process, this paper proposes a methodology that measures productivity change across companies and over time when sample sizes are extremely small. Since it follows an index-number approach, the main advantage of the proposed methodology is that it applies to comparative performance measurement under regulation, where consideration of both spatial and temporal differences in TFP is necessary for setting appropriate X- factors (Fox et al., 2003). This advantage is especially important because for many countries, the number of regulatory companies can be very small. By reconciling spatial and temporally chained indices, productivity comparisons across firms and over time are carried out. The introduction of quality issues in productivity measures allows further decomposition of the TFP into two additional factors, the quality catch-up by less productive firms and the quality growth achieved by the benchmark firm.

Our empirical analysis of indicated that by 2002 , quality improvements contributed to the productivity performance of the England and Wales WaSCs. After 2002, the average company achieved significant levels of catch-up in quality-adjusted productivity until 2005. After 2005 high levels of productivity catch-up were no longer indicative of general productivity improvement. Regarding quality issues, the results indicate that until 1997 there were small gains in average quality relative to benchmark quality, but that after 1998, average quality substantially exceeded benchmark quality.

The proposed $X$ factors provide evidence that based on a quality-unadjusted assessment, WaSCs need to improve productivity by an average of $2.64 \%$ over a period of five years. When quality issues are introduced, the average $X$ factor increases to $3.26 \%$. This means that on average, WaSCs need to improve their productivity with existing inputs (or reduce their costs) toward the performance of the benchmark firm by $3.26 \%$. 
The methodology and results of this study should be of great interest to water (or other services) regulators interested in developing comparative performance measurement when sample sizes (number of regulated companies) is extremely limited. Moreover, appropriate $X$ factors in price-cap regulation provide essential incentives for improving the efficiency and productivity of water companies. This study represents our first attempt at providing a methodology for setting $X$ factors for the WaSCs of England and Wales. In spite of the usefulness of the index number methodology applied, a limitation is that the available data do not allow us to readily account for differences in operating characteristics and service quality of service that may affect relative measures of productivity or price performance. Future research will focus on how differences in operating characteristics and service quality could be employed in a non-frontier approach, that is, index number techniques. Moreover, the work could be repeated using SFA or DEA to include desirable and undesirable outputs (for example, related to various service-quality factors), and to judge the sensitivity of results to the choice of methodology. Finally, this study focused only on WaSCs. The same exercise could be applied to clean water supply activities by including WoCs as well, which would indicate the overall performance of the water services industry in England and Wales.

\section{ACKNOWLEDGMENTS:}

The authors would like to express their gratitude for the support of the Economic and Social Science Research Council as well as the Office of Water Services (Ofwat). The views expressed in the paper are those of the authors and no representation is made that they are shared by bodies providing financial support for the research.

\section{REFERENCES}

Ashton, K. J. 2000. Cost efficiency in the UK water and sewerage industry. Applied Economic Letters, 7: 455-458.

Balk, B.M. 1996. A Comparison of Ten Methods for Multilateral International Price and Volume Comparison. Journal of Official Statistics, Vol. 12, No. 2, 199-222.

Barrett, G. and Wallace, M. (2011). An Institutional Economics Perspective: The Impact of Water Provider Privatisation on Water Conservation in England and Australia. Water Resources Management, 25 (5): 1325-1340. 
Bernstein, I. J., Hernandez, J., Rodriguez, J.M. and Ros, A.J. 2006. X-Factor updating and total factor productivity growth: the case of peruvian telecommunications 1996-2003. Journal of Regulatory Economics, 30 (3): 316-342.

Bottasso, A., Conti,M., 2009. Scale economies, technology and technical change: evidence from the English Water only sector. Regional Science and Urban Economics, 39(2), 138-147.

Coelli, T. and Walding, S. 2006. Performance Measurement in the Australian Water Supply Industry: A Preliminary Analysis, In Performance measurement and regulation of network utilities (ed. T. Ceolli and D. Lawrence), Edward Elgar.

Diewert, E.W. and Lawrence, D. 2006. Regulating electricity networks: The ABC of setting X in New Zealand, In Performance measurement and regulation of network utilities (ed. T. Ceolli and D. Lawrence), Edward Elgar.

Erbetta, F. and Cave, M. 2007. Regulation and efficiency incentives: Evidence from the England and Wales water and sewerage industry. Review of Network Economics, 6 (4), 425-452.

Fox, K.J., Grafton, R.Q., Kirkley, J. and Squires, D. 2003. Property rights in a fishery: Regulatory change and firm performance. Journal of Environmental Economics and Management, 46 (1): 156-177.

González-Gómez, F., García-Rubio, M.A., Alcalá-Olid, F. and Ortega-Díaz, M.I. (2013). Outsourcing and Efficiency in the Management of Rural Water Services. Water Resources Management, 27 (3): 731-747.

Guerrini, A., Romano, G. and Campedelli, B. (2013). Economies of Scale, Scope, and Density in the Italian Water Sector: A Two-Stage Data Envelopment Analysis Approach. Water Resources Management, 27 (13): 4559-4578.

Hernández-Sancho, F., Molinos-Senante, M., Sala-Garrido, R. and Del Saz-Salazar, S. (2012). Tariffs and efficient performance by water suppliers: an empirical approach. Water Policy, 14: 854-864.

Hill, R.J. 2002. Measuring Price Differences Across Space and Time: The Case of the European Union's Harmonized Index of Consumer Prices. Discussion Paper, School of Economics, The University of New South Wales.

Hill, R.J. 2004. Constructing price indexes across space and time: The case of the European Union. American Economic Review, 94 (5): 1379-1410. 
Hwang, W.-S. and Lee, J.-D. 2013. Profitability and productivity changes in the Korean electricity industry. Energy Policy, 52: 531-542.

Hunt, L.C., and Lynk, E.L. (1995). Privatization and efficiency in the UK water industry: an empirical analysis. Oxford Bulletin of Economics and Statistics, 57 (3): 371-388.

Lawrence, D., Diewert, W.E. and Fox, K.J. 2006. The contributions of productivity, price changes and firm size to profitability. Journal of Productivity Analysis, 26 (1): 1-13.

Lawrence, D. and Kain, J. 2012. The Total Factor Productivity Performance of Victoria's Gas Distribution Industry. Report prepared for Envestra Victoria, Multinet and SP AusNet.

Lynk, E.L. 1993. Privatization, joint production and the comparative efficiencies of private and public ownership: the UK water industry case. Fiscal Studies, 14 (2): 98-116.

Marques, R.C. 2008. Comparing private and public performance of Portuguese water services. Water Policy, 10 (1), 25-42.

Marques, R.C., Simões, P. and Pires, J.S. 2011. Performance benchmarking in utility regulation: The worldwide experience. Polish Journal of Environmental Studies, 20 (1): 125-132.

Marques, R.C. and Monteiro, A.J. 2003. Measuring productivity and efficiency of water and sewerage utilities: A total factor productivity approach. II International Conference: Efficiency use and management of urban water supply, Tenerife, Canary Islands, Spain.

Maziotis, A., Saal, D.S. and Thanassoulis, E. 2012. Profit, productivity and price performance changes in the English and Welsh Water and Sewerage companies. FEEM Working Paper, Nota Di Lavoro, No.84.

Maziotis, A., Saal, D.S. and Thanassoulis, E. 2009. Regulatory Price Performance, Excess Cost Indexes and Profitability: How Effective is Price-cap regulation in the Water Industry?, Aston Business School Working Papers, RP 0920.

Maziotis, A., Saal, D.S. and Thanassoulis, E., Molinos-Senante, M. 2015. Profit, productivity and price performance changes in the water and sewerage industry: an empirical application for England and Wales. Clean Technologies and Environmental Policy, 17, 1005-1018.

Molinos-Senante, M., Maziotis, A. and Sala-Garrido, R. 2014. The Luenberger productivity indicator in the water industry: an empirical approach for England and Wales. Utilities Policy, In press. 
Molinos-Senante, M., Maziotis, A., Mocholí-Arce, M., Sala-Garrido, R. 2015. Accounting for service quality to customers in the efficiency of water companies: evidence from England and Wales. Water Policy, In press.

O'Donnell, C.J. 2004. Measuring and decomposing agricultural productivity and profitability change. Australian Journal of Agricultural and Resource Economics, 54 (4): 527-560.

Pellegrino, R., Ranieri, L., Costantino, N., Mummolo, G. 2011. A real options-based model to supporting risk allocation in price-cap regulation approach for public utilities. Construction Management and Economics, 29 (12), 1197-1207.

Pierani, P. 2009. Multilateral comparison of total factor productivity and convergence in Italian agriculture (1951-2002). DEPFID Working Papers - 2, University of Sienna, Italy.

Portela, M.C.A.S., Thanassoulis, E., Horncastle, A. and Maugg, T. 2011. Productivity change in the water industry in England and wales: Application of the meta-Malmquist index. Journal of the Operational Research Society, 62 (12): 2173-2188.

Saal, D.S. and Parker, D. 2000. The impact of privatization and regulation on the water and sewerage industry in England and Wales: a translog cost function model. Managerial and Decision Economics, 21 (6): $253-268$.

Saal, D.S. and Parker, D. 2001. Productivity and Price Performance in the Privatized Water and Sewerage Companies in England and Wales. Journal of Regulatory Economics, 20 (1): 61-90.

Saal, D.S., Parker, D. and Weyman-Jones T. 2007. Determining the contribution of technical efficiency, and scale change to productivity growth in the privatized English and Welsh water and sewerage industry: 1985-2000. Journal of Productivity Analysis, 28 (1): 127-139.

Saal, D.S. and Reid, S. 2004. Estimating OPEX productivity growth in English and Welsh water and sewerage companies: 1999-2003. RP0434. Aston Business School Research Papers.

Salerian, J. 2003. Analysing the performance of firms using a decomposable ideal index number to link profit, prices and productivity. The Australian Economic Review, 2 (36): 143-55.

Waters II, W.G. and Tretheway, M.W. 1999. Comparing Total Factor Productivity and Price Performance: Concepts and Application to the Canadian Railways. Journal of Transport Economics and Policy, 33 (2): 209-22. 
Ye, S., Tiong, R.L.K. 2003. Tariff adjustment frameworks for privately financed infrastructure projects. Construction Management and Economics, 21 (4), 409-419. 